\title{
Value of Character Education in Grebeg Saparan Traditional Ceremony of Cukilan Village
}

\author{
Diah Retnaningtyas Utami ${ }^{1}$, Andayani ${ }^{2}$, Sumarwati ${ }^{3}$ and Kundharu Saddhono ${ }^{4}$ \\ \{retnaningtyas.utami@gmail.com ${ }^{1}$,bu_anda09@yahoo.com ${ }^{2}$ \& watik_uns@ymail.com ${ }^{3}$, \\ kundharu_s@staff.uns.ac.id $\left.{ }^{4}\right\}$ \\ 1,2,3 Universitas Sebelas Maret, Surakarta, Indonesia
}

\begin{abstract}
The local wisdom of the Javanese community needs to be maintained and developed. This is an effort to keep upholding the values of local wisdom in the millennial generation. The form of Javanese local wisdom can be material and nonmaterial culture. Material leads to real community creations such as culinary, clothing, houses, traditional ceremonies, and others. Where as nonmaterial refers to folklore, traditional games, perfoming art, and others. In addition, many traditional ceremonies also contain the value of character education that can be applied in daily life. From of this study is descriptive qualitative which source of data are grebeg saparan traditional ceremony. Data collected using in-depth interview and observation to support data analysis. In this study aims to explain how the process of implementing Grebeg Saparan in Cukilan Village are form of preserving Javanese local wisdom and what value of character education are contained in the traditional ceremony. The Grebeg Saparan was held on Friday Wage in Safar month with great fanfare. The character education contained in Grebeg Saparan are religious value, tolerance value, hard work value, creative value, friendly/ communicative value, envireonmental care value, social caring value, and responsibility value.
\end{abstract}

Keywords: character education, grebeg saparan, traditional ceremony

\section{INTRODUCTION}

Local wisdom comes from two words namely wisdom and local. In general, local wisdom can be understood as local ideas that are wise, full of wisdom, good value, embedded and followed by members of the community. Local wisdom is a product of the past culture that should be continuously taken into hold in life [1]. Local wisdom becomes a manifestation of certain people's intellectual intelligence as well as the accumulation of their life experiences. Thus, the concept of local wisdom is used to describe cultural values and local wisdom [2]. This reinforces that local wisdom is attached to good character that can be applied in daily life.

Rituals are traditional scaraments that are performed in socio-religious setting and term can be used interchangeably with rites. Rituals of various kinds are feature of almost all known human societies with each community having rituals that can be prescribed by tradition 
of that community [3]. Grebeg Saparan is held in Krajan II, Cukilan Village, Suruh SubDistrict, Semarang Regency. This ceremony has become a general custom. Grebeg Saparan is held annually by the people of Cukilan Village for commendable as a tribute to Ki Ageng Wanakusuma who has devoted his attention to the field of religion and the welfare of the surrounding population to the end of his life. A tradition can continue, usually because it has a foundation or certain historical background that accompanies it [4].

Cukilan Village is one of the villages located in Suruh District, Semarang Regency which has a traditional ceremony as a form of local wisdom in the form of Grebeg Saparan traditional ceremony. This traditional ceremony is held regularly every year. The fading factor of this activity is the lack of awareness and understanding and importance of customs in the community and the rapid era of globalization, so there is an assumption that traditional ceremonies are an ancient or outdated thing. A ritual is an activation system or series of actions arranged by custom or law that applies in the community that are related to the types of permanent events that usually occur in the community concerned. Traditional ceremonies have rules and the procedure determined by the community or group of creators of the ritual, so that each ritual has a difference, both in terms of implementation or equipment. Rituals are also a form of respect for The Lord, Gods, Ancestors, and Spirits [5]. The preserve of customs in the form of traditional ceremonies is part of the traditional cultural defense system [6].

Grebeg Saparan was a ceremony held to commemorate the commendable of Ki Ageng Wanakusuma who had spread Islam in the region which was carried out as a symbol of gratitude and the birth of Ki Ageng Wanakusuma, praying The concept of ritual in the Islamic tradition is not only related to it worship ceremony to God, but also as a tourist facility spiritual that can arouse people's religious awareness in preserving rural cultural preservation by giving a total offering that Ki Ageng would be accepted by God because he was one of the propagators of religion [7].

\section{METHOD}

The research method used in this study is qualitative descriptive. Qualitative research is research that produces descriptive data in the form of written or oral words from people or observed behavior [8].The location of the research was in Cukilan Village, Suruh Subdistrict, Semarang Regency. The informants were taken from community leaders who knew about Grebeg Saparan. Data collection techniques were obtained based on descriptive methods with observation techniques and interview. Data collection is done by reviewing text, recording and analysis. The data analysis technique uses the technique to see and note. Data that has been classified, inventoried, then analyzed its meaning carefully and analytically. This analysis is interactive which includes four research components, namely; (1) data collection, (2) data reduction, (3) data presentation, (4) conclusion.

\section{RESULT AND DISCUSSION}

\subsection{Background of Traditional Ceremony of Grebeg Saparan}

A difference in mindset, a social system, truth, genetic, even aspects geographical have the effect culture formation. Several factors above who made the culture of region with each other become different [9]. Grebeg Saparan is one form of ceremony that is still carried out by the people in Cukilan Village, a cultural heritage that is still believed even though the reliance held today do not teach any belief or reliance in an object or tomb. But the people in Cukilan Village were able to combine the two with no contradiction, even though they grew various syncretism. Syncretism is a mixture of Islam with local elements, so that Islam no longer 
appears in its original form, but has mixed with external elements, so that Islam in Cukilan Village (which is carried out by the community) is Islam that has united in itself local and non-Islamic elements. With syncretism, it is able to make people have cultural property that may not be found elsewhere. As one example of syncretism, which is believed to be seen during implementation, namely its implementation on 1 Sapar. Similarly, the prayers used in rituals are verses in the Islamic religion, as well as the means of offerings that must be prepared in the form of incense, flowers and others. With a combination of religious teachings that are believed and other reliance are able to enrich a variety of cultures that were born in the midst of the community, especially in the Cukilan village.

Grebeg Saparan program in the month of Safar precisely on Friday "Wage" was not only attended by the local community but many residents from various regions who in fact were far away also participated in enlivening the event. Since long time ago, "Saparan" seemed to be an obligation that could not be left by the Cukilan people, even community members who had migrated far from outside Java were placed to go home following the Grebeg Saparan. Actually this event aims to look at the grave of respected families such as parents, grandparents, children or other relatives who have died. But on the other hand this tradition also has a meaningful salvation ceremony for Cukilan community leaders namely Ki Ageng Wanakusumo. Ki Ageng Wanakusumo was the first person to live in this Cukilan Village. At that time the state of Cukilan was still chaotic, there were large trees and could be said to be bulak senthe (as the local community called the forest). The arrival of Ki Ageng Wanakusuma brought a big change. Starting from a small hut to one, two houses and developed into a connection that can now be visited. With the tradition of Grebeg Saparan, the tomb seems to have turned into a night market with many seasonal traders selling their wares around the tomb. All benefited from the parking attendants, small traders, tomb cleaners, mat tenants, grave caretakers who became prayer interpreters. They get annual fortune through the tradition of Grebeg Saparan. The cultural community has advantages and disadvantages which can be used as strategic force in improving the quality of life, so they can be used to create prosperity for local communities around [10].

\subsection{The Implementation of Traditional Ceremony of “Grebeg Saparan”}

Society and culture are a system that could not be separated, because no culture does not develop in a society. In the contrast, there are no people who do not have culture because without culture there is no a meaningful life. Society is a place and culture is the content [11]. Grebeg Saparan is a term in Javanese that is used by local people in the area of Cukilan Village, Suruh Sub-district as a tradition of the peak of the saparan event at the Ki Ageng Wanakusuma tomb. This tradition, which is one of the cultural tourism agenda of Semarang Regency, is routinely held on Friday Wage in the month of Safar. The peak event is held on Friday Wage Safar month at noon around 13.00 WIB. Implementation is supported by several elements, which are carried out sequentially. The sequence of procession participants is as follows Village Elders, Some people use Wanakusuma clothing, Village officials, Carrier dondang and ubarampe, Carrier Gunungan, Wanakusuma escort troops, and local communities.

The procession begins by arranging the sequence of participants, starting from the Tjunction of neighborhood association (RT) 1 administrative unit at the next to-lowest level in city (RW) I across the main village road and finally focusing on the implementation of Grebeg Saparan. After the parade arrived at a designated place, they were welcomed by residents who did not take part in the procession by holding a mat or other seat and preparing a place to put 
the tumpeng (ceremonial dish of yellow rice served in a cone shape). After all the parade arrived near the tomb, the Grebeg Saparan event began with the following program:
a. Opening
b. Parade from neighborhood association (RT) 1 to the tomb
c. Handover of the shroud from the regent then handed over to the tomb keeper
d. Shroud replacement

The tomb keeper who has received the new shroud replacing the old shroud, immediately replaces it because this is the main of the series of events. This was held in the tomb of Ki Ageng Wanakusuma and was accompanied by members of the carnival. The old shroud was replaced with a new one, then the caretaker and members of the caravan did their homage and offered prayers to Allah SWT.

e. Speech from the subdistrict

f. Speech from Semarang Regency Regent

g. Tahlil,kenduri, and closing prayer

h. Grebeg Gunungan. At the end of the ceremony the residents snatch away of the Gunungan, which consists of various kinds of produce from Cukilan village.

\subsection{Character Education in Grebeg Saparan}

In the context of education, character education is a conscious effort that is done to form learners into positive and noble personality according to the competency standards of graduates (SKL) so that it can be implemented in everyday life. Character education has three main functions: firstly the function of formation and development of potential, both the reREMr and reinforcement function, the three filter functions of the negative things. [12]

Through character education, all commit to developing participants students become whole individuals internalize virtue (know, want), and get used to realizing inner virtues everyday life [13]. Find the noble value of education character in culture Indonesia is not difficult. That matter because of the Indonesian people known as a still nation uphold noble customs and cultures. In essence, the values of noble characters can be found in customs and culture every tribe of this country [14].

In the current education system, Indonesia is supportive about strengthening character education values in learning. This is intended to instill early on the values of character education so that students will get used to and imitate it. Education is means not only to provide knowledge and information, but also to build character of human being. Having a set of values and ideals, learners must be guided for self-development, so that values become a part of their character [15]. Character education implemented in learning in schools includes 18 character education, including: (1) religious, (2) honesty, (3) tolerance, (4) discipline, (5) hard work, (6) creative, (7) independent, (8) democratic, (9) curiosity. (10) national spirit, (11) love for the homeland, (12) respect for achievement, (13) friendly / communicative, (14) love for peace, (15) love to read, (16) care for the environment, (17) social care and (18) responsibility. Therefore, as the younger generation are expected to have an awareness on the cultural wealth of their own and are expected to have a sense of morality and ethics which is held in high esteem solidarity and cooperativeness, strengthening of empathy humanity, harmony and tolerance in diversity, and uphold the existence and the natural sustainability of their residence [16].

Grebeg Saparan also has character education values. The following are character education values that can be described based on the Grebeg Saparan ceremony that are. 


\section{Religious value}

Grebeg Saparan is expected to be able to increase faith and piety to God because implicitly the event is a symbol of our gratitude towards God.

2. Tolerance value

This tolerance value can be seen when all or all levels of society participate together and do not think about social stratification, all blending into one for the smoothness of the event.

\section{Hard work value}

Grebeg Saparan will not run well and smoothly without the hard work of the committee in particular and all levels of society in general. Everything drains energy and mind to offer the best.

\section{Creative value}

Grebeg Saparan contains creative values can be seen from the development of Grebeg Saparan" from year to year there is always renewal and there is always innovation to increase the attractiveness of visitors.

\section{Friendly / Communicative value}

In Grebeg Saparan can be seen the value of friendship from the results of proximity to each other. With such solidarity there will be a conducive atmosphere to support everything for the smooth running of activities. In addition, with the "Grebeg Saparan" event bringing together all levels of society that should indeed be united without a barrier, because all humans are the same in the presence of God.

\section{Environmental Care value}

In Grebeg Saparan, the tomb is considered a historic heritage that must always be maintained and cared for as best as possible.

\section{Social Caring value}

Grebeg Saparan can be cause to emerge for others, be more care to what is around us and can minimize selfishness.

\section{Responsibility value}

Grebeg Saparan also teaches about responsibility when the traditional ceremony will be the responsibility of the next generation who are expected to always maintain and preserve the tradition [17][18].

\section{CONCLUSION}

Cukilan Village is one of the villages that still uphold local wisdom in the form of Grebeg Saparan which is still carried out routinely every year. Grebeg Saparan is still carried out with great fanfare and all residents work together well to make the event run smoothly. In addition, "Grebeg Saparan" has many good values to be applied in daily life. The character education contained in Grebeg Saparan are religious value, tolerance value, hard work value, creative value, friendly/communicative value, environmental care value, social caring value, and responsibility value. 


\section{REFERENCE}

[1] Simajuntak, Bungaran Antonius. Korelasi Kebudayaan dan Pendidikan : Membangun Pendidikan Berbasis Budaya Lokal. Penerbit Yayasan Pustaka Obor Indonesia (2014)

[2] Suswandari. Kearifan Lokal Etnik Betawi. Penebit Pustaka Pelajar ( 2017)

[3] Babane, M.T. \& Chauke, M.T. The Preservation of Xitsonga Culture through Rainmaking Ritual: An Interpretative Approach. Stud Tribes Tribals Journal, 13 (2), 108-114 (2015)

[4] Suwarno. Tradisi Manten Mubeng Gapura di Masjid Loram Kulon. Jurnal Patra Widya pp 57-72 (2016)

[5] Koentjaraningrat: Kebudayaan Jawa. Jakarta: PN. Balai Pustaka (1984)

[6] Indiatmoko, Bambang: Mertidesa Desa Gowak Pringsurat Temanggung Sebagai Bentuk Revitalisasi Pemertahanan Kearifan Lokal Jawa. Prosiding Seminar Nasional Kearifan Jawa UNNES pp 116-123 (2017)

[7] Ilahi, Muhammad Takdir. Kearifan Ritual Jodangan Dalam Tradisi Islam Nusantara Di Goa Cerme. Jurnal Kebudayaan Islam pp 42-58 (2017)

[8] Moeleong, Loxy J. Metodologi Penelitian Kualitatif. Bandung: Remaja Karya (2017)

[9] Setyawan, B. \& Kundharu Harmonia: Ceprotan Performing Art: A Traditional Folkart Based on Urband Legend Harmonia: Journal of Arts Research and Education 18 (1) pp 67-73 (2018)

[10] Oktavia, Renny \& Mawardi I. Islamic Values in the Tradition of Samin Community in East Java. QIJIS: Qudus International Journal of Islamic Studies Renny Oktafia and Imron Mawardi Volume 5 issue 1 pp 97 - 113 (2017)

[11] Tanduk, Rita et al. Symbolization of Meaning of Singgi Tedongin Traditional Ceremony Merauk Tongkonan Rambutuka at Tana Toraja. International Journal of Science of Research Volume 5 PP 2036 - 2042 (2015)

[12] Amini, et al. The Development of Character Education Model Trough an Integrated Curriculum at Elementary Education Level in Medan City. IJLRES - International Journal on Language, Research and Education Studies Vol. 1, No. 2, Page: 298 - 311 (2017)

[13] Suwija, I Nyoman. Nilai -Nilai Pendidikan Karakter Dalam Pembelajaran Bahasa Bali. Jurnal Pendidikan Karakter pp 67 - 80 (2012)

[14] Wahyuningsih. Maguti: Nilai Pendidikan Karakter Dalam Masyarakat Jawa (Sebuah Kajian Simbolisme dalam Budaya Jawa). Jurnal Media Prestasi pp 155 - 169 (2018)

[15] Shoba, Sundaresan \& Kala, Nandakumar. Value Education towards Empowerment of Youth-a Holliday Approach. Social and Behavioral Sciences Journal, 172 pp 192-199 (2015)

[16] Syarif, Erman, et al. Conservation Values of Local Wisdom Traditional Ceremony Rambu Solo Toraja's Tribe South Sulawesi as Efforts the Establishment of Character Education. EFL Journal, 1 (1), pp 17-23 (2016)

[17] B.W. Setyawan and K. Saddhono, "Eret traditional ceremony as representation of spirit of mutual cooperation among coastal communities". Adv. Sci. Let. vol. 23 no.10, pp 9991-9992, 2017

[18] K. Saddhono and S. Supeni. "The role of dutch colonialism in the political life of Mataram dynasty: A case study of the manuscript of Babad Tanah Jawi." Asian Soc. Sci. vol. 10 no. 15 pp. $1-7,2014$ 